УДК 159.9: 330.16

DOI: $10.26565 / 2225-7756-2019-67-08$

\title{
PSYCHOLOGICAL HEALTH IN THE CONTEXT OF ECONOMIC BEHAVIOR: THEORETICAL REVIEW OF THE PROBLEM
}

Zharikova Svitlana Borysivna, candidate of psychological sciences, docent of department of psychology, National Aerospace University H.E. Zhukovsky "Kharkiv Aviation Institute", Kharkiv, Hvardiytsiv-Shyronintsiv str., 69/42, apt.108

Жарікова Світлана Борисівна, кандидат психологічних наук, доцент кафедри психології, Національний аерокосмічний університет ім. М.С. Жуковського "ХАI", м. Харків, вул. Гвардійців Широнінців, 69/42, кв. 108

Жарикова Светлана Борисовна, кандидат психологических наук, доцент кафедры психологии, Национальный аэрокосмический университет им. Н.Е. Жуковского «ХАИ», г. Харьков, ул. Гвардейцев - Широнинцев, 69/42, кв. 108

ORCID - 0000-0002-6814-6415

e-mail: zharik.svet@gmail.com

The article presents a theoretical overview of the problem of psychological health in the context of economic behavior. It is stated that the relevance, theoretical and practical significance of the problem of psychological health is confirmed in numerous researches of modern scientists, which allows to mark it as one of the priority among the developed psychological problems. In the context of constant socio-economic changes, the problem of the psychological health of the personality becomes of particular importance. Economic changes, which is one of the components of the transformation processes that take place in Ukrainian society, set the specific environmental context of the functioning of the psychological health of a personality. The content of "psychological health» concept and its criteria are considered. The following approaches to understanding this phenomenon are indicated: socio-psychological, ontogenetic, professional, moral-psychological, general-psychological and resource. It is stated that scientists clearly define such a perspective of psychological health functioning as the optimality and constructiveness of interaction with the environment and the world as a whole, which makes it possible to consider adequate economic behavior as one of the aspects of such interaction. The analysis of the concept of "economic behavior» in terms of economic and psychological science, as well as its types such as financial behavior, conservation behavior, debt behavior, investment behavior, "poverty behavior» is presented. On the basis of the analysis of modern theoretical and empirical researches the connection of psychological health and economic behavior is determined, the contribution of a number of psychological characteristics to the functioning of different types of economic behavior is revealed. It is noted that the economic side of life of a modern person living in a transformational society is one of the significant variables in the formation of psychological health, the condition of which, in this context, is economic behavior that is adequate to the ongoing and predicted changes.

Key words: types of economic behavior; criteria for psychological health; personality; psychological health; economic behavior

У статті представлений теоретичний огляд проблеми психологічного здоров'я в контексті економічної поведінки. Обтрунтовано актуальність досліджень означеної проблеми. Розглянуто зміст поняття «психологічне здоров'я», його критерії та індикатори, позначені підходи до розуміння цього феномену. Представлено аналіз поняття «економічна поведінка» з точки зору економічної та психологічної науки, а також його видів. На основі аналізу сучасних теоретичних $і$ емпіричних досліджень визначено зв'язок психологічного здоров'я та економічної поведінки. Зазначено, що економічний вектор додає нові змінні в прочес формування психологічного здоров'я особистості, умовою забезпечення якого виступає адекватна наявним і прогнозованим змінам економічна поведінка.

Ключові слова: види економічної поведінки; критерії психологічного здоров'я; особистість; психологічне здоров'я; економічна поведінка

В статье представлен теоретический обзор проблемы психологического здоровья в контексте экономического поведения. Обоснована актуальность исследований обозначенной проблемы. Рассмотрены содержание понятия «психологическое здоровье», его критерии и индикаторы, обозначены подходы к пониманию этого феномена. Представлен анализ понятия «экономическое поведение» с точки зрения экономической и психологической науки, а также его видов. На основе анализа современных теоретических и эмпирических исследований определена связь психологического здоровья и экономического поведения. Указано, что экономический вектор добавляет новые переменные в прочесс формирования психологического здоровья личности, условием обеспечения которого выступает адекватное имеющимся и прогнозируемым изменениям экономическое поведение.

Ключевые слова: виды экономического поведения; критерии психологического здоровья; личность; психологическое здоровье; экономическое поведение 
Problem formulation. The relevance, theoretical and practical significance of the problem of psychological health is confirmed in numerous studies of modern scientists. This allows us to designate it as one of the priority among the developed psychological problems. In the context of constant socio-economic changes, the problem of the psychological health of a personality acquires special significance.

A characteristic feature of modern social reality is the high rate of change in various spheres of social life, which gives rise to variability and inconsistency in all spheres of human life. Transformational processes that unfold in the socio-political and economic life of society, the crisis of social reality exert a sociogenic stress on the personality. Along with androgenic and psychogenic factors, sociogenic factors can be one of the causes of human health disorders, an important component of which is psychological health. It, in turn, is a factor in both the overall well-being of the subject and the basis of the effectiveness of his professional activity. In order to function effectively in today's society and maintain psychological health, one must not only possess such qualities as stress tolerance, initiative, enterprise, readiness to innovate, willingness to risk and compete, but also the ability to implement models of effective economic behavior.

At the same time, the problem of psychological health functioning in the context of economic behavior remains unresolved. It should be noted that the interaction of these psychological phenomena in both theoretical and empirical perspectives has received little attention in modern science. This is what determined the purpose of the article.

The purpose of the article is to carry out a theoretical analysis of the problem of psychological health in the context of economic behavior in Ukrainian-language and Russian-language studies.

Analysis of recent research. According to the stated purpose, this analytical review focuses on scientific explorations aimed at studying both the phenomenon of psychological health and the problem of economic behavior, which has acquired a cross-sectoral character in modern science.

\section{The phenomenon of psychological health}

The problem of psychological health is one of the most pressing problems of modern psychological sciences - both in theoretical and practical perspective.

In order to specify the meaning of the concept of «psychological health», it is necessary to distinguish it with the widely used concept of «mental health».

I.V. Dubrovina, who introduced the concept of «psychological health» into scientific discourse, notes that the term «mental health» refers to individual mental processes and mechanisms, while the term «psychological health» should be referred to as a whole. Psychological health, according to this researcher, is closely related to the higher manifestations of the human spirit. Such an understanding allows us to distinguish the psychological aspect of mental health as opposed to medical, sociological, philosophical, etc. The author emphasizes that psychological health makes a person self-sufficient $[1, \mathrm{p} .6]$.

Attempts at positive definition of psychological health, as stated by M.A. Kuznetsov and L.M. Zotova, researchers are focusing not so much on ailments and internal conflicts, but on a person's ability to maintain mental well-being and well-being through the activation of cultural, social and intrapersonal mechanisms for maintaining health. Currently, many concepts are used to reveal the essence of psychological health and its mechanisms. These are - survival, stability of personality, its harmony, subjective well-being, selfcare, psychological protection, strategies and styles of overcoming stress, adaptive and personal potential, resources, perception of social support, attributive style, sanogenic aspects of self, health-saving personalities quality, internal picture of health [2, p.122].

This multi-vector of the phenomenon of psychological health explains the multiplicity of approaches available to its understanding:

- Socio-psychological approach involves the use of the term «public mental health», which refers to the level of mental health of large groups [3, p.19];

- Ontogenetic approach considers the peculiarities of forming the psychological health of the individual and the conditions for his support at different stages of ontogenetic development [3, p.20];

- Professional approach focuses attention on various aspects of professional formation and professional behavior as factors of psychological health of the individual [3, p.23].

- Moral-psychological approach, representatives of which relate the psychological health of the individual with its moral development, the process of assimilation of moral knowledge, the formation of moral ideas, the adoption of moral norms and the development of moral qualities of the person [3, p.23];

- General psychological approach considers the most general patterns of psychological health formation [3, p.25].

In addition, in contemporary psychology, the phenomenon of psychological health has been studied within a resource approach. Through the lens of the resource model, psychological health is considered in two aspects: as a result, a certain condition, and as a powerful aggregate psychological resource that provides an adequate state, behavior and development of the individual. In this case, the main components of psychological health and, accordingly, its resource components can be intellectual, emotional, spiritual, moral and ethical, social, creative health and the like. Within the resource model, psychological health is considered in the toolresource (as the potential of the possible) and productive-activity (as the potential of the achieved) aspects. The potential of the possible is defined as the balance between external (environmental and cultural-historical) and internal (resources and constraints) conditions [4, p.82].

In a meaningful perspective, psychological health is understood as a state of psychological well-being provided by a set of personal qualities and properties that are a prerequisite for a person's vitality, constructive capture of his needs and successful self-realization. In the views on psychological health tendencies to define 
it as the equivalent of socio-psychological adaptation (the power of «Ego», corresponding to the cognitive and affective maturity, regulatory mechanisms, moral maturity) are observed; equivalents of personal growth, selfactualization, the equivalent of the spiritual, actualization of the human in a person, as well as a combination of these strokes [5, p.178 - 179].

In the structural-functional sense, psychological health is considered as a complex phenomenon containing the cognitive-evaluative component of biological, psychological and social levels of its provision, where the exclusive role belongs to the higher psychological formations, which fulfill the functions of organization, regulation and maintenance of the integrity of the life path [3, p.167].

The structure of psychological health, according to research by A.V. Kozlov, represented by eleven spheres: absence of mental deviations, mental equilibrium, pro-social orientation, physical well-being, humanistic position, desire to be oneself, creative expression, family well-being, spirituality, goal orientation, intellectual[6, p.265]. namely:

L.M. Karamushka and T.M. Dziuba distinguishes the determining criteria for psychological health,

- Well-developed reflection, stress resistance, ability to find own resources in difficult situation; completeness of emotional and behavioral expressions of personality, reliance on one's own inner self;

- Self-acceptance and ability to cope with their emotional difficulties without harming others, "selfobjectivity" as a clear idea of their strengths and weaknesses, the presence of a system of values that contain the main purpose and make sense of everything that a person does;

- Orientation of development and character of actualization of the human in the person;

- The nature and dynamics of the basic processes that determine the life of an individual, in particular, the change of its properties and features at different age stages [7, p. 27 - 28].

The key indicators of a person's psychological health are personal integrity, self-fulfillment and selfregulation. Ancillary indicators at the individual-psychological level are creativity, balance, adaptability; at the value-semantic level - it is the search for new meanings, the comprehension of experience, the ability to enjoy life and at the socio-psychological level - is the tendency to cooperate, the ability to empathize, responsibility to society $[8, \mathrm{p} .146]$.

I.I. Haletska emphasizes that psychological health is the embodiment of social, emotional and spiritual well-being (as a resource and condition), as it is a potential prerequisite for meeting the vital needs of an active lifestyle, achieving one's goals, adequate and optimal interaction with people, social and other environment. Psychological health is the embodiment of the results of the socialization of the individual and a factor in the effectiveness of this process and individual development, while defining the features of social and psychological adaptation [9, p. 53]. In addition, the scientist notes that psychological health is an integrative system, which, among other things, is a prerequisite for ensuring optimal interaction with the environment [10].

The importance of psychological health as a factor of constructive interaction of personality with the environment is emphasized by a number of authors.

A.V. Petrovsky and M.G. Yaroshevsky, in defining the concept of «psychological health», focus on the basic functions of psychological health, one of which is to maintain the balance between personality and environment [11].

O.I. Shevchenko proposes to consider psychological health as a dynamic equilibrium of a person with the surrounding natural and social environment. Such an equilibrium allows one to fulfill social functions in full and acts as one of the important conditions for the proper functioning of the individual [12].

Increasing interest in psychological health problems S.E. Pokrovskaya explains, in particular, the constant complication of lifestyles and interpersonal relationships, the rapid flow of information, the variability of the environment, which places increased demands on human mental activity [13, p.248].

O.A. Nizdran views psychological health as a state of dynamic balance between the demands of the world and the unveiling of one's own potential by a person who is embodied in his experience of subjective well-being [14, p.21].

Consequently, scientists clearly outline such a perspective on the functioning of psychological health as the optimality and constructiveness of interaction with the environment and the world at large.

In the environmental context, it should be noted that "today in the history of mankind there are processes characterized by radical transformations at the level of logic of its existence. Instead of the previous social reality, which has exhausted its historically conditioned potential, a new type of social reality (and man) is coming. ... The unique component of the functioning of such a «new» society, an important sphere of social life, one of the essential «mechanisms» of creation and reproduction of the world in which the modern man is and acts, is the socio-economic sphere of social life, which, apparently, corresponds to the type a certain «economic person» who is the carrier of the properties of the subject of this socio-economic social sphere» [15, p.286]. The multi-factorial model of an economic person covers a wide range of characteristics and integral indicators of its viability [16, p.453]. In today's realities, the «homo economicus» approach has undergone significant changes, and, according to the followers of these ideas, for the modern man the importance is not so much material, but spiritual benefits (the need for self-realization, the connection with other people, satisfaction with the process of work, its complexity and social significance, etc.) [17, p. 252].

Thus, the economic vector of environmental change adds new variables to the process of formation of the psychological health of the individual, by which the economic behavior is adequate to the ongoing and predicted changes. 


\section{Economic behavior: the psychological content of the problem}

The notion of «economic behavior» is actively elaborated in economics and psychology, and differences in the understanding of economic behavior by these sciences are fundamental. From the point of view of economics, economic behavior refers to the form of human activity as an economic agent, or his conscious activity in the field of management. Economic behavior, which is the subject of consideration of psychologists, is treated as a phenomenon due to the peculiarities of needs, motives, resources of the individual [18, p.65].

Economic behavior is aimed at subjective optimization due to the comparison of available resources with the possible benefits from their use, both material and non-economic [19, p.10]. Economic behavior is defined as the activity of the personality, related to the disposal of economic resources and aimed at meeting the needs of the subject. In the structure of economic behavior allocate affective, cognitive and connective components. Economic behavior has a value-meaning conditionality, which means that the subject of economic relations exists in the system of choosing the type of economic activity, depending on its values, moral orientations, life principles, goals and aspirations [18, p.76 - 77].

The structure of economic behavior includes the following components: economic emotions and feelings, for example, satisfaction from economic success and achieved status; economic perception, an example in this sense is the perception of money or goods; economic ideas, that is, ideas about how the economy functions; economic thinking, the person's ability to reflect and comprehend economic concepts, to understand their essence, to assimilate and correlate them with the requirements of economic laws and to build their activities on the basis of this [20].

Formation of economic behavior determines the needs and resources of the subject as well as a factor of economic behavior is a holistic set of conditions (psychological, social, economic) environment and activity [21, p.22]. The whole set of social norms and values acts as a regulator of economic behavior [22, p.65].

Consider the psychological contexts of individual types of economic behavior.

Financial behavior refers to a person's behavior when opening deposits and taking out loans, playing games on exchanges, as well as investing in securities. Financial behavior can be considered in terms of both savings and debt behavior. Savings behavior is determined by the following motives: the motive for managing money, the motive for the buffer, which preserves money for overcoming possible financial difficulties, the motive for targeted savings, ensuring the preservation of money for the purpose of purchase in the future, the motive for managing money. Deferred compensation is more fun in the future, which is why this term is fundamental to psychological research. Uncertainty is the main determinant of retention behavior. Uncertainty in financial prosperity in the future frightens a person, because of which she has a desire to save money. People, who take care of their finances, monitor and administer them, and also have an internal locus of control and are focused on economically positive development, are more prone to retaining behavior [23, p. 87].

With regard to the individual psychological characteristics of people who are prone to retention behavior, extraversion is found to be a predictor of impulsive behavior. In societies where extraversion is more valued, people are less likely to retain behavior. Extroverts attach more importance to living standards and are more prone to demonstrative consumption to confirm status. People who are characterized by retentive behavior are less likely to be at risk. The results of several studies indicate that extroverts are more at risk thus, extraversion is negatively correlated with retention behavior [23, p. $87-88]$. Debt behavior is expressed in the acquisition of debt and is the opposite of a retention behavior.

Investment behavior is associated with the impact of risk-taking, with people at risk rather than the opportunity to win, but assessing the potential loss in losing. The explanation is that the person gives the psychological value to the money and their loss leads to psychological trauma. Investment behavior is influenced by a positive or negative attitude to money. What is more important is the attitude of the person to investing: whether she considers it a fair income or a frivolous act. In short-term investments, the emotional factor has a big influence, which is why rational decision-making suffers. Long-term investments are characterized by greater rationality and thoughtfulness due to the reduced influence of emotions on decision making [23, $\mathrm{p}$. 88 - 89].

M.Yu. Semenov examined monetary behavior and found that mature individuals are less valuable in money and have higher levels of monetary satisfaction. They form a more rational and conscious attitude to money, which is perceived as a means, and their fetishization does not occur, the prevailing attitudes towards rational consumer behavior. Personally mature people are more likely to learn new rules of behavior in an economic situation, more confident in financial matters, in a situation of insignificance more often oriented to an objective and rational perception of the situation and to find a solution to the problem. The motives for spending money are to a greater extent the motives of creativity, cognition, self-development, altruistic help to other people [24].

One of the types of economic behavior is the so-called "poverty behavior", that is, the behavior of persons who are psychologically gravitating towards poverty.

Such persons are clearly lacking in reflective abilities about the causes of their poverty, social status, their life goals, values and relationships with the surroundings. In this case, the inability (small experience) and reluctance (weak motivation) to reflect are inherently combined and condition each other. Conformism as a basal characteristic of the bearers of a culture of poverty has been recorded by scientists in two manifestations: an attempt to meet public opinion and expectations, and fear of having their own opinions [14, p.40].

On the basis of generalization of scientific achievements presented in modern psychological literature, O.A. Nizdran states that it is psychological health is related to economic status. People with low economic 
status make up a social segment that remains within the low-income (have low income) and experience a decline in psychological health [14, p.43]. The author has empirically proved that persons with low economic status, compared to the insured persons, are characterized by the following indicators of psychological health: expressed social frustration, frustration with the level of their education, financial status, living and living conditions, possibility of choosing a place of work; lower levels of subjective economic well-being, positive relationships with others, autonomy, self-acceptance and psychological well-being, financial deprivation, financial stress are more pronounced [14, p.214].

So, the facts cited in the research publications indicate that productive economic behavior distinguishes individuals with psychological characteristics that are considered constructive. At the same time, subjects with certain non-constructive psychological characteristics tend to have unproductive economic behavior.

Conclusions. The convergence of the research interests of representatives of economic and psychological science seems to be extremely important not only for studying the behavior, motives and values of a person that influence economic behavior, but also acquires special significance for studying the problem of psychological health in an appropriate context.

Psychological health is regarded as a complex, multi-vector phenomenon, which is reflected in a number of approaches to its understanding, namely, social-psychological, ontogenetic, professional, moralpsychological, general-psychological and resource approaches.

Scientists have identified the determining criteria of psychological health and its indicators, emphasized the importance of optimality and constructive interaction of the individual with the environment to maintain psychological health.

In one of the dimensions of interaction with the environment, the person acts as an economic agent, whose activity is due to the peculiarities of needs, motives, resources, which determine the content of its economic behavior. Productive economic behavior is correlated with positive psychological characteristics, while individuals characterized by certain negative psychological characteristics are inherent in the manifestations of unproductive economic behavior.

Economic changes, which is one of the components of the transformation processes that are unfolding in Ukrainian society, set the specific environmental context of the functioning of the psychological health of the individual.

Thus, the economic side of the life of a modern person living in a transformational society is one of the significant variables in the formation of psychological health, the condition for which in this context is economic behavior adequate to the content of those changes that are happening or predicted.

Limitations and future research. There are some limitations of the current study that should be noted.

The first limitation concerns the choice of Ukrainian-language and Russian-language research publications related to the problem under consideration, although various aspects of the relationship of psychological health and economic behavior are actively studied by foreign researchers. In connection with the longer history of studying this problem abroad and the large amount of accumulated scientific facts, it is recommended that an independent research publication be devoted to a detailed analysis of foreign experience in the study of psychological health in the context of economic behavior as a prospect for further work in the chosen direction. This will make it possible to further compare the research results of Ukrainian and Russian authors with the data obtained in studies of psychological health and economic behavior both in countries with developed economies and in third world countries.

The second limitation that should be acknowledged is that studies of unemployment as a form of economic behavior were not included in the analytical review. Undoubtedly, unemployment is an important social problem, to which a great deal of research is devoted. In addition, as noted by N.O. Seryogina, its growth undermines the mental health of the nation[25, p.94]. The unemployed are not a homogeneous social group that has to be taken into account in studies of the problem identified. In particular, the official status of an unemployed person, even confirmed by registration in employment centers, does not exclude employment in the shadow economy. The share of shadow employment among the total employed population in Ukraine, although decreased by $1,1 \%$, still remains significant at $20,7 \%$ [25, p.92]. Unemployed as a social group is also heterogeneous in terms of motivation: a certain number of unemployed are motivated to actively seek work, others implement paternalistic aspirations, expecting the help of the state, or are non-motivated to retrain and change their profession. Therefore, given the importance and complexity of the problem, it would be appropriate to highlight this area of research in future work. For future research, it is recommended that in a review of studies on the issue of psychological health in the context of unemployment as one of the types of economic behavior, pay attention to the analysis of strategies for selecting subjects and forming a sample.

Furthermore, further research of psychological health in the context of economic behavior, in our opinion, should be carried out with the inclusion of a wider range of psychological variables in the research plans, which will enrich the scientific understanding of the content of the phenomena under study and the relationships between them.

Література

1. Дубровина И. В. Психическое здоровье детей и подростков / И. В. Дубровина. - Екатеринбург : Деловая книга, 2000. - 176 с.

2. Кузнецов М. А. Психологические механизмы и детерминанты поддержания здоровья человека / М. А. Кузнецов, Л. Н. Зотова // Вісник ХНПУ ім. Г. С. Сковороди. Серія : Психологія. $-2018 .-$ №. 53. - C. 102-125. 
3. Жигалкіна Н. В. Особливості ставлення до психологічного здоров'я особистості : дис. ... канд. психол. наук : 19.00.01 / Н. В. Жигалкіна. - Одеса, 2017. - 199 с.

4. Петров В. Г. Счастье и психологическое благополучие в ресурсной модели психологического здоровья / В. Г. Петров, К. В. Злыгостева // Acta Biomedica Scientifica. - 2015. - №. 4. - С. 79-83.

5. Маланьїна Т. М. До проблеми психологічного здоров'я / Т. М. Маланьїна // Вісник Чернігівського національного педагогічного університету. Психологічні науки. - 2015. - № 128. - С. 176-179.

6. Козлов А. В. Психологическое здоровье как аспект становления личности / А. В. Козлов // Актуальні питання теорії та практики психолого-педагогічної підготовки фахівців за соціономічним профілем : матеріали Всеукраїнської науково-практичної конференції (Хмельницький, 22-23 травня 2010 р.) / Ред. колегія: О. А. Каденко (голов. ред.), Л. О. Подкоритова та ін. - Хмельницький : ХНУ, 2011. - С. 264 - 265.

7. Карамушка Л. М. Феномен «здоров'я» як актуальний напрям досліджень в організаційній психології / Л. М. Карамушка, Т. М. Дзюба // Організаційна психологія. Економічна психологія. - 2019. - T. 1. - №. 16. - С. 22-33.

8. Титаренко Т. М. Психологічне здоров'я особистості: засоби самодопомоги в умовах тривалої травматизації / Т. М. Титаренко. - Кропивницький : Імекс-ЛТД, 2018. - 160 с.

9. Галецька I. I. Психологічне здоров’я як проблема національної безпеки / I. I. Галецька // Науковий вісник Львівського державного університету внутрішніх справ. Серія психологічна. - 2012. - №. 2 (1). - С. 49-58.

10. Галецька I. Критерії психологічного здоров’я / І. Галецька // Вісник Львівського університету. Філософські науки. - 2007. - Вип. 10. - С. 317-328.

11. Петровский А. В. Краткий психологический словарь / А. В. Петровский, М. Г. Ярошевский. - Москва : Политиздат, 1985. - 431 с.

12. Шевченко Е. И. Концептуальное понимание категории «психологические здоровье» / Е. И. Шевченко // Вісник ОНУ. - 2013. - Т.18, вип. 4(30). - С. 308 - 315.

13. Покровская С. Е. Экопсихология: социальный и индивидуальный подход к здоровью личности / С. Е. Покровская // Актуальні проблеми психології. - 2008. - Т. 7, вип. 15. - С. 244 - 249.

14. Ніздрань О. А. Соціальний капітал як чинник підтримання психологічного здоров'я осіб із низьким економічним статусом : дис. ... канд. психол. наук : 19.00.05 / О. А. Ніздрань. - Київ, 2017. - 256 с.

15. Бондаренко О. В. Сучасна «економічна людина» та цінності розвитку економічної культури: людиновимірність економічного розвитку / О. В. Бондаренко // Гілея: науковий вісник. - 2016. - Вип. 107 (4). - C. 286-291.

16. Петінова О. Б. Економічна людина у соціально-філософському дискурсі : дис. ... докт. філос. наук : 9.00.03 / О. Б. Петінова. - Одеса, 2017. - 503 с.

17. Бушенева Ю. И. Экономическое поведение: обзор основных подходов / Ю. И. Бушенева // XIX Царскосельские чтения. - 2015. - С. 251-255.

18. Евдокимова А. С. Социально-психологические факторы экономической социализации личности : дис. ... канд. психол. наук: 19.00.05 / А. С. Евдокимова. - Иркутск, 2014. - 186 с.

19. Миронова Т. Ю. Социально-психологические особенности экономической социализации подростков и юношей : автореф. дис. ... канд. психол. наук : 19.00.05 / Т. Ю. Миронова. - Курск, 2013. $-23 \mathrm{c.}$

20. Душков Б. А. Психология труда, управления, инженерная психология и эргономика / Б. А. Душков, А В. Королев, Б. А. Смирнов. - М. : Деловая книга, 2005. -572 с. $-236 \mathrm{c}$.

21. Полякова Н. В. Экономическое поведение / Н. В. Полякова. - Иркутск : Изд-во ИГЭА, 1998.

22. Негруль В. В. Экономическое поведение и целостность общества: параметры взаимной детерминации / В. В. Негруль // Вестник ВГУ. Серия : Философия. - 2015. - №. 4. - С. 58-68.

23. Патоша О. И. Психологические факторы экономического поведения / О. И. Патоша // Вестник науки и образования. - 2019. - № 1-2. - С. 86-89.

24. Семенов М. Ю. Особенности отношения к деньгам у людей с различным уровнем личностной зрелости : дис. ... канд. психол. наук : 19.00.05 / М. Ю. Семенов. - Ярославль, 2004. - 178 с.

25. Серьогіна Н. О. Безробіття як внутрішня загроза національній безпеці / Н. О. Серьогіна // Економіка та держава. - 2019. - № 3(11). - С. 89 - 95.

\section{References}

1. Dubrovina, I. V. (2000). Psikhicheskoe zdorov'e detei i podrostkov v kontekste psikhologicheskoi sluzhby. Ekaterinburg: Delovaya kniga. (in Russian)

2. Kuznetsov, M. A., \& Zotova, L. N. (2018). Psikhologicheskie mekhanizmy determinanty podderzhaniya zdorov'ya. Visnyk KhNPU im. G.S.Skovorody” Psykhologiya”, (53), 102-125. Retrieved from http://dspace.hnpu.edu.ua/handle/123456789/179 (in Russian)

3. Zhygalkina, N.V. (2017). Osoblyvosti stavlennja do psyhologichnogo zdorov 'ja osobystosti. (Dysertacija kandydata nauk). Retrieved from http://pub.onu.edu.ua/k4105107-psykholohichni-nauky (in Ukrainian)

4. Petrov, V. G., \& Zlygosteva, K. V. (2015). Schast'e i psikhologicheskoe blagopoluchie v strukture resursnoi modeli psikhologicheskogo zdorov'ya Byulleten' Vostochno-Sibirskogo nauchnogo tsentra 
Sibirskogo otdeleniya Rossiiskoi akademii meditsinskikh nauk. (4), 79-83. Retrieved from https://www. actabiomedica.ru/jour/article/view/96 (in Russian)

5. Malan'i'na, T. M. (2015). Do problemy psyhologichnogo zdorov'ja. Visnyk Chernigivs'kogo nacional'nogo pedagogichnogo universytetu. Psyhologichni nauky, (128), 176-179. Retrieved from http:// nbuv.gov.ua/UJRN/VchdpuPH 2015 12840 (in Ukrainian)

6. Kozlov, A. V. (2011). Psikhologicheskoe zdorov'e kak aspekt stanovleniya lichnosti. In O.A. Kadenko (golov. red.), Aktual'ni pytannja teorii' ta praktyky psyhologo-pedagogichnoi' pidgotovky fahivciv za socionomichnym profilem (pp. 264 - 265). Retrieved from https://kafedra-psy.at.ua > materialy_ konferencii 2011-maket (in Russian)

7. Karamushka, L. M., \& Dzjuba, T. M. (2019). Fenomen «zdorov'ja» jak aktual'nyj naprjam doslidzhen' v organizacijnij psyhologii'. Organizacijna psyhologija. Ekonomichna psyhologija, 1(16), 22-33. https://doi.org/10.31108/2.2019.1.16.2. (in Ukrainian)

8. Tytarenko, T. M. (2018). Psyhologichne zdorov'ja osobystosti: zasoby samodopomogy v umovah tryvaloi' travmatyzacii'. Kropyvnyc'kyj: Imeks-LTD. (in Ukrainian)

9. Galec'ka, I. I. (2012). Psyhologichne zdorov'ja jak problema nacional'noi' bezpeky. Naukovyj visnyk L'vivs'kogo derzhavnogo universytetu vnutrishnih sprav. serija psyhologichna, (2 (1)), 49-58. Retrieved from http://nbuv.gov.ua/UJRN/Nvldu_2012_2\%281\%29_8 (in Ukrainian)

10. Galec'ka, I. (2007). Kryterii' psyhologichnogo zdorov'ja. Visnyk L'vivs'kogo nacional'nogo universytetu im. I. Franka. Serija: Filosofs'ki nauky, ( 10), 317-328. Retrieved from https://www.academia. edu/2039924/\%25D0\%259A \%25D0\%25A0\%25D0\%2598\%25D0\%25A2\%25D0\%2595\%25D0\%25A0\% $25 \mathrm{D} 0 \% 2586 \% 25 \mathrm{D} 0 \% 2587 \% 25 \mathrm{D} 0 \% 259 \mathrm{~F} \% 25 \mathrm{D} 0 \% 25 \mathrm{~A} 1 \% 25 \mathrm{D} 0 \% 2598 \% 25 \mathrm{D} 0 \% 25 \mathrm{~A} 5 \% 25 \mathrm{D} 0 \% 259 \mathrm{E} \% 2-$ 5D0\%259B\%25D0\%259E \%25D0\%2593\%25D0\%2586\%25D0\%25A7\%25D0\%259D\%25D0\%259E \%2 5D0\%2593\%25D0\%259E_\%25D0\%2597\%25D0\%2594\%25D0\%259E\%25D0\%25A0\%25D0\%259E $\% 2$ $5 \mathrm{D} 0 \% 2592 \% 25 \mathrm{D} 0 \% 25 \mathrm{AF}+\& \mathrm{~cd}=2 \& \mathrm{hl}=\mathrm{ru} \& \mathrm{ct}=\mathrm{clnk} \& \mathrm{gl}=\mathrm{ua}($ in Ukrainian) (in Russian)

11. Petrovskii A.V., \& Yaroshevskii M.G. (1985) Kratkii psikhologicheskii slovar'. Moskva: Politizdat.

12. Shevchenko, E. I. (2013). Kontseptual'noe ponimanie kategorii psikhologicheskoe zdorov'e. Visnyk Odes'kogo nacional'nogo universytetu. Psyhologija, (18, (4), 308-315. Retrieved from http://dspace. onu.edu.ua:8080/bitstream/handle/123456789/5011/308-315.pdf\%3Fsequence\%3D1\%26isAllowed\%3Dy+ $\& \mathrm{~cd}=1 \& \mathrm{hl}=\mathrm{ru} \& \mathrm{ct}=\mathrm{clnk} \& \mathrm{gl}=\mathrm{ua}$

13. Pokrovskaja, S. E. (2008). Jekopsihologija: social'nyj i individual'nyj podhod k zdorov'ju lichnosti. Aktual'ni problemy psyhologii', (7 (15)), 244 - 249. Retrieved from http://appsychology.org.ua/index.php/ua/ arkhiv-vydannia/tom-7?start=11 (in Russian)

14. Nizdran', O.A. (2017). Social'nyj kapital jak chynnyk pidtrymannja psyhologichnogo zdorov'ja osib iz nyz'kym ekonomvchnym statusom. (Dysertacija kandydata nauk). Retrieved from http://ispp.org.ua/ avtoreferati-disertaci\%d1\%97-vidguki-opponentiv-socialna-psixologiya/ (in Ukrainian)

15. Bondarenko, O. V. (2016). Suchasna ekonomichna ljudyna ta cinnosti rozvytku ekonomichnoi' kul'tury: ljudynovymirnist' ekonomichnogo rozvytku. Gileja: naukovyj visnyk, (107), 286-291. Retrieved from http://eir.zntu.edu.ua/handle/123456789/2963?mode=full (in Ukrainian)

16. Petinova, O.B. (2017). Ekonomichna ljudyna u social'no - filosofs'komu dyskursi (Dysertacija doktora nauk). Retrieved from http://dspace.pdpu.edu.ua/handle/123456789/871 (in Ukrainian)

17. Busheneva, Yu. I. (2015). Ekonomicheskoe povedenie: obzor osnovnykh podkhodov. In V.N. Skvortsov, L.M. Kobrin (Red.). XIX Tsarskosel'skie chteniya (pp. 251-255). Retrieved from https:// cyberleninka.ru/article/n/ekonomicheskoe-povedenie-obzor-osnovnyh-podhodov (in Russian)

18. Evdokimova, A. S. (2014). Sotsial'no - psikhologicheskie faktory ekonomicheskoi sotsializatsii lichnosti (Disertatsiya kandidata nauk). Retrieved from https://www.twirpx.com/file/1593705/ (in Russian)

19. Mironova, T. Yu. (2013). Sotsial'no-psikhologicheskie osobennosti ekonomicheskoi sotsializatsii podrostkov i yunoshei (Avtoref. disertatsii kandidata nauk). Retrieved from https://kursksu.ru/dissertations/ dis368.pdf $+\& \mathrm{~cd}=1 \& \mathrm{hl}=\mathrm{ru} \& \mathrm{ct}=\mathrm{clnk} \& \mathrm{gl}=\mathrm{ua}$ (in Russian)

20. Dushkov, B.A., Korolev, A.V., \& Smirnov, B.A. (2005). Psikhologiya truda, upravleniya, inzhenernaya psikhologiya i ergonomika. M.: Delovaya kniga. (in Russian)

21. Polyakova, N.V. (1998). Ekonomicheskoe povedenie. Irkutsk: Izd-vo IGEA, 1998. (in Russian)

22. Negrul', V. V. (2015). Ekonomicheskoe povedenie i tselostnost' obshchestva: parametry vzaimnoi determinatsii. Vestnik VGU. Seriya: Filosofiya, (4), 58-68. Retrieved from http:/www.vestnik.vsu.ru/pdf/ phylosophy/2015/04/2015-04-03.pdf $+\& c d=1 \& h l=$ ru\&ct=clnk\&gl=ua (in Russian)

23. Patosha, O. I. (2019). Psikhologicheskie faktory ekonomicheskogo povedeniya. Vestnik nauki i obrazovaniya, (1-2), 86-89. Retrieved fromhttps://cyberleninka.ru/article/v/psihologicheskie-faktoryekonomicheskogo-povedeniya-1 (in Russian)

24. Semenov, M.Yu. (2004). Osobennosti otnosheniya k den'gam u lyudei s razlichnym urovnem lichnostnoi zrelosti (Disertatsiya kandidata nauk). Retrieved from https://www.twirpx.com/file/238242/ (in Russian)

25. Ser'ogina N.O. (2019). Bezrobittja jak vnutrishnja zagroza nacional'nij bezpeci. Ekonomika ta derzhava, (3(11)), 89 - 95. Retrieved from http://www.pa.economy.in.ua/ (in Ukrainian) 